\title{
A Novel Human Hair Protein Fiber Prepared by Watery Hybridization Spinning
}

Yoshitoshi Hirao $^{1}$, Kousaku Ohkawa ${ }^{2}$, Hiroyuki Yamamoto ${ }^{2}$, Toshihiro Fujii ${ }^{1, *}$

${ }^{1}$ Department of Kansei Engineering, ${ }^{2}$ Institute of High Polymer Research, Faculty of Textile Science and Technology Shinshu University, Tokida 3-15-1, Ueda 386-8567, Japan

* Fax: +81-268-21-5518; E-mail: fujiit1@giptc.shinshu-u.ac.jp

Published in Macromolecular Materials and Engineering. 290(3): 165-171 (2005) 
Full Paper: A novel human hair protein hybrid fiber was developed by combining (i) the high-efficiency extraction technique for preparing human hair proteins and (ii) the watery hybridization spinning method using gellan and chitosan. The resulting human hair protein-gellan-chitosan hybrid fibers are conveniently produced with by simply mixing the 7-35\% human hair protein-1.0 wt-.\% gellan aqueous solution and the $1.0 \mathrm{wt}-\%$ chitosan-0.15M acetic acid solution at $50{ }^{\circ} \mathrm{C}$, followed by pulling out to spin the human hair protein-gellan-chitosan ternary complex thus formed at the aqueous solution interface. By use of this simple procedure and ambient spinning condition, the human hair proteins were successfully incorporated into the fiber matrix of gellan-chitosan, without any denature and degradation. The hybrid fiber can be also recognized as a new type of the regenerated human hair keratin fiber, because of its high purity and content of human hair keratin types I and II. Mechanical strength of the human hair protein-gellan-chitosan fiber varies from 108 MPa to $153 \mathrm{MPa}$, depending on the contents of the human hair proteins. SEM observation revealed that the incorporated human hair proteins were found as the particles $(1-10 \mu \mathrm{m})$ on the fiber surface. The type I and II keratins in the fiber matrices were rapidly biodegraded by chymotrypsin within $30 \mathrm{~min}$, and the digested fragments slowly released from the fiber matrices. Thus, the human hair hybrid fiber is a very promising material having a broad spectrum of applications as the engineering fibers, particularly for the medical uses, because the human hair proteins are easily available, biocompatible, and bioresorbable materials.

Keywords: chitosan; gellan; human hair proteins; hybrid fiber; keratin, self-assembly

\section{Introduction}

Many excellent fiber materials occur in nature. Among these materials, silk and wool are two of the strongest animal fibers in their tensile properties. Natural fibers are important materials not only for the cultures of the human race since the ancient times but also for the present technologies and industries. Natural fibrous polymers, for examples, animal hair keratin, silk fibroin, tendon collagen, muscle myosin, and cotton cellulose, have attracted researchers in the interdisciplinary fields of investigations, because of their well-designed material performances and functions based on the evolutional conservation, which are full of the interplay between the basic science and applied technologies. ${ }^{[1-3]}$ Particularly, the polymer chemistry involved in the wool ${ }^{[4-6]}$ and silk ${ }^{[7,8]}$ spinning processes has been two of the central interests in both biopolymer science and fiber industries for a prolonged period and also at the present.

In the present study, we attempted to create a novel material science associated with the keratin, a major component of the animal hairs, and focused on the human hairs as the easily available and low-cost keratin sources. Recently, we reported the novel extraction method of the human hair proteins. ${ }^{[9]}$ This method, referred to as "Shindai method", does not require any detergents but recovers the human hair proteins at the maximum yield greater then $70 \%$. Later we demonstrated that a translucent and flexible film is conveniently prepared by casting the human hair extractson a flat pan. ${ }^{[10,11]}$ The film thus obtained possesses practical mechanical strength, elevated biocompatibility towards human skins, ${ }^{[11]}$ and biodegradability by several proteases. ${ }^{[12]}$

Use of the human hair proteins, which are prepared by the Shindai method, finds three advantages. First, the human hairs are of the extraorganismic materials from self-origin. This means that the human hair proteins have an expected potential for the biomedical applications, which are free from the allergic reaction if the human hair protein-based medical material is prepared from and implanted to the identical personal. Second, the human hair proteins undergo the biodegradation by in vivo proteases, suggesting that the human hair 
proteins will be developed as a resorbable biomaterial, which eliminates the need for surgical removal after implantation. Third, the human hair proteins are mainly composed of the $\alpha$-keratin and small amount of the matrix proteins. Keratin is the most abundant component in animal hairs, nails, horns, and feathers, and occurs approximately $50 \%$ of the total mass. ${ }^{[13,14]}$ The $\alpha$-keratin are highly cross-linked with each other by disulfide bonds, resulting in forming the hardened and insoluble extracellular organs. ${ }^{[15]}$ Thus, the human hair protein-based materials are expected to be tough and stable in their mechanical and chemical properties.

The earliest attempt to prepare the regenerated fibers utilizing the extracted keratins from animal hairs was described by Wormell in 1949. ${ }^{[16,17]}$ Since then, there have been numerous researches to develop the extracted keratins as the engineering materials, many of which are the regenerated wool or its composite fibers, films, and coatings. ${ }^{[18-24]}$ Apart from these approaches, more recently from the polymer chemical standpoint, Yamamoto et al reported the new type silk-like ${ }^{[25]}$ and wool-like ${ }^{[26]}$ hybrid fibers through the polyionic complexation reaction between the two counter-charged polypeptides and/or polysaccharides (reviewed in $\left.{ }^{[27,28]}\right)$. The complexation reaction is driven by the self-assembling between polyanionic and polycationic polymers at the aqueous solution interface. The polymer complex thus formed is directly spun into a water-insoluble hybrid fiber. This method, namely the watery hybridization spinning, can be performed under the ambient procedures with simple spinning apparatus.

The combination of the Shindai method for the human hair protein extraction and the above spinning technique further inspires an idea to develop a novel human hair protein-based fiber material. Here we consider the incorporation of the extracted human hair proteins into the polysaccharide hybrid fiber matrix, by means of the watery hybridization spinning. A set of the counter-charged polysaccharides, the anionic gellan and the cationic chitosan, were chosen because of the following reasons; (i) gellan and chitosan are available in a large quantity for mass production, (ii) the gellan-chitosan hybrid fiber exhibited a practical tensile strength, ${ }^{[29]}$ (iii) the gellan-chitosan hybrid fiber can be spun at the relatively low solution concentrations ranging from 0.75 to $1.0 \mathrm{wt}-. \%,{ }^{[30]}$ and this allows the human hair proteins to be incorporated as the most major component (above $7 \mathrm{wt}-. \%$ or more) in the hybrid fiber matrix, (iv) chitosan and gellan are polysaccharide, so that, by use of proteases, only the biodegradability of the incorporated human hair proteins can be selectively evaluated, and (v) the gellan-chitosan hybrid fiber is actually biodegraded by environmental microorganisms, ${ }^{[31]}$ implying that the human hair protein-gellan-chitosan hybrid fiber can be developed not only as the biomedical but also the environmental engineering materials. ${ }^{[32]}$

In the following experiments, we prepared the human hair protein-gellan-chitosan ternary complex at the aqueous solution interface, followed by spinning the complex into the hybrid fiber. The resulting hybrid fiber was characterized in its surface morphology, mechanical property, and biodegradability.

\section{Experimental Part}

\section{Materials}

Gellan (comprising 1,3- $\beta$-D-glucose, $1,4-\beta$-D-glucuronic acid, $1,4-\beta$-D-glucose and 1,4- $\alpha$-L-rhamnose ${ }^{[33]}$ ) was purchased from San-Ei-Gen F.F.I., Ind. Chitosan $[(1 \rightarrow 4) \text {-2-amino-2-deoxy- } \beta \text {-D-glucan }]^{[34]}$ was purchaes from Wako Pure chemical Ind. Japan.

\section{Preparation of Human Hair Proteins}

Human hair proteins were extracted according to the Shindai method described in our 
previous articles. ${ }^{[9-11]}$ The extract was dialyzed against distilled water for 3 days and immediately used in a series of experiments.

\section{Spinning of Human Hair Protein-Gellan-Chitosan Hybrid Fiber}

Human hair protein solution was prepared at $0.1,0.25,0.5$, and $0.75 \mathrm{wt}-\%$ by diluting the human hair extracts to distilled water. Gellan gum was dissolved at 1 wt-.\% in distilled water at $50^{\circ} \mathrm{C}$, and the gellan solution was mixed with the human hair protein solution to the final concentration of 0.75 vol.-\%. Chitosan was dissolved at $1.0 \mathrm{wt}-. \%$ in $0.15 \mathrm{M}$ acetic acid. The human hair protein/gellan solution was slowly added onto the chitosan solution. Immediately, the human hair proteins, gellan and chitosan spontaneously associated via the polyionic complexation to form the gel-like hybrid material at the solution interface. Using a pincette the hybrid material was pulled up vertically from the interface, immediately then it was continuously spun into a wet thread. The wet thread was passed through a 3-liter ethanol bath (1.5 m long and $35 \mathrm{~mm}$ deep) in order to dehydration, air-dried at room temperature, and rolled up by a motor. The gellan-chitosan fiber was prepared as the control sample by the same procedure.

\section{Characterization of Hybrid Fiber}

Scanning electron microscopy (SEM) was performed using a Hitachi S-2380N microscope. Intact fiber samples were adhered to the gold holder using an electrically conductive carbon double-sided stick tape and imaged at $18 \mathrm{kV}$. The mechanical properties of the PIC fibers were evaluated using an Orientec STA- 1150 Tensilon at $25^{\circ} \mathrm{C}$ and $50 \%$ relative humidity. The initial gauge length was $20 \mathrm{~mm}$, and the load was generated at $20 \mathrm{~mm} \cdot \mathrm{min}^{-1}$. The average stress-strain curves were determined from 20 independent measurements. The cross-sectional area, $A\left(\mathrm{~mm}^{2}\right)$, was estimated from the equation, $A=\pi(\phi / 2)^{2}$, where $\phi$ is the average diameter (mm) determined using an optical microscope. The tensile stress (MPa) was defined as the load $(\mathrm{N})$ per $A\left(\mathrm{~mm}^{2}\right)$ at the rupture of the specimen. The strain (\%) was calculated from the increase in length of a specimen during a tensile test, expressed as the percentage of the initial gauge length.

\section{Biochemical Analysis}

Protein concentrations in the extracts from the human hairs or the hybrid fibers were determined according to a protocol for the commercially available Bio-Rad protein assay kit (Bio-Rad), based on the colorimetric quantification, which was originally reported by Bradford. $^{[35]}$ Protein concentrations were calculated using the standard curve of bovine serum albumin.

Sodium dodecyl sulfate-polyacrylamide gel electrophoresis (SDS-PAGE; 13.5\% slab gel) was performed according to the method of Laemmli. ${ }^{[36]}$ Human hair proteins in the gel were stained with $0.1 \%$ Coomassie brilliant blue R-250 in 10 vol-.\% acetic acid-40 vol-.\% ethanol for $1 \mathrm{~h}$, then in 45 vol-.\% acetic acid-45 vol-.\% ethanol for decolorization of the background. Enzymatic Digestion of Human Hair Proteins

Digestion of the human hair proteins in the fiber matrix was performed with chymotrypsin. Chymotrypsin was dissolved in a Tris-buffered saline (TBS; $20 \mathrm{mM}$ Tris-HCl, $137 \mathrm{mM} \mathrm{NaCl}$, $\mathrm{pH} 7.5)$ at $1 \mathrm{mg} \cdot \mathrm{mL}^{-1}$. The hybrid fiber containing $7 \%$ human hair proteins (5 mg) was cut into the small pieces and immersed into the chymotrypsin/TBS solution $(1 \mathrm{~mL})$. The weight ratio of fiber sample and chymotrypsin was fixed at 50:1. The enzymatic digestion was carried out for $0,30,60,90$, and $120 \mathrm{~min}$ at $35^{\circ} \mathrm{C}$. ${ }^{[12]}$ The digestion was terminated by immersing the fiber samples into the distilled water and washed repeatedly by centrifugation. The remaining human hair proteins were quantified by extracting the proteins according to 
Shindai method, followed by the Bradford's protein assay of the extract, as described above.

\section{Results and Discussion}

Preparation of Human Hair Protein-Gellan-Chitosan Hybrid Fiber

Five kinds of the human hair protein-gellan-chitosan hybrid fibers were successfully prepared by the watery hybridization spinning (Figure 1). The contents of the human hair proteins in the fiber matrices were experimentally determined and the fiber samples were designated according to the percentage of the protein weight to the fiber weight, as follows; 7 wt-.\% human hair protein fiber (HPF), 16\%-HPF, 23\%-HPF, and 35\%-HPF. The gellan-chitosan fiber is the control ( $0 \mathrm{wt}-. \%$ of the human hair proteins). Comparing the gellan-chitosan fiber with the other HPF samples, their colors gradually change from white (the control, Figure 1a) to beige (35\%-HPF, Figure 1e), as the contents of the human hair proteins increases. All HPFs were continuously produced using a wet-spinning apparatus accompanied by a winding moter. A mean HPF lengths of 25 meters are yielded from 240 mg of human hair proteins, which corresponds to the average content in the hair mass one adult person grows everyday.

The mean diameter increases depending on the contents of the human hair proteins: $50 \mu \mathrm{m}$, the control gellan-chitosan fiber; $67 \mu \mathrm{m}, 7 \%$-HPF; $81 \mu \mathrm{m}, 16 \%$-HPF; $106 \mu \mathrm{m}, 23 \%$-HPF; 110 $\mu \mathrm{m}, 35 \%-\mathrm{HPF}$.

\section{Surface Morphology}

SEM photographs of the control and the HPF samples were showed in Figure 2. The control gellan-chitosan fiber exhibited the fibrils arranged in parallel with the fiber axis. The HPF samples have the similar fibril structures, and in addition, the particles could be found on the fiber surfaces (Figure 2b-2e). The size of particle increases with the contents of the human hair proteins. The mean diameters of the particles were $1 \mu \mathrm{m}$ and $10 \mu \mathrm{m}$ for $7 \%$-HPF and 35\%-HPF, respectively. This fact suggests that these particles mainly contain the human hair proteins.

In order to discuss the relationship between the morphologies of HPFs and the contents of the human hair proteins, the human hair proteins were solubilized from the HPFs by the Shindai method, then the protein contents were qualitatively determined by SDS-PAGE (Figure 3). The lane 1 in Figure 3 represents the band pattern of the human hair proteins extracted from the native human hairs. Type I keratin (40-50 kDa) and type II keratin (55-60 $\mathrm{kDa})$ are the major components of this preparation, as we have previously reported. ${ }^{[12]}$ Microfibril proteins and matrix proteins are also found in relatively smaller amounts. As for the control and the HPF samples, the protein contents were examined by the same procedure (Figure 3, lanes 2-6). The control sample contains no protein (Figure 3, lane 2). The solubilized amount of type I keratin, type II keratin, and matrix proteins from the HPF samples became enriched as increasing the protein contents in the pre-spun solution (Figure 3, lanes 3-6). This result indicates that human hair proteins are certainly incorporated in fiber matrices, without any decomposition during the spinning procedures. Furthermore, the human hair proteins are retained to be stable in fiber matrices at least for few months after spinning.

\section{Mechanical Properties}

Figure 4 represents mechanical properties of the control and HPF samples. The gellan-chitosan fiber exhibited a tensile strength values (strain at break) of $171 \mathrm{MPa}$ and an extensibility value (elongation at break) of $8.3 \%$. The tensile strength value of the HPFs decreased in the following order: 7\%-HPF (153 MPa) > 16\%-HPF (152 MPa) > 23\%-HPF (134 MPa) > 35\%-HPF (108 MPa). The elongation at break values of the HPFs also 
decreased in the following order: 23\%-HPF (8.1\%) > 7\%-HPF (7.7\%) > 16\%-HPF (7.7\%) > 35\%-HPF (6.2\%). These results indicate that the toughness of the HPF decreases almost linearly with increasing the content of the human hair proteins in the HPF. There are two possible mechanisms to be considered for the decrease in toughness of the HPF at the higher human hair protein content. One is a physical mechanism that the surface roughness with particles (Figure 2) causes the increased frequency of the stress concentration. The other is a chemical mechanism that coexistence of both acidic (type I) and basic (type II) keratins (Figure 3) interfere with the electrostatic interaction between gellan and chitosan. The yield point values are almost constant in the stress-strain curves of the control and all HPF samples (data not shown), suggesting that the physical mechanism predominantly contribute to the change in mechanical properties of the HPF samples.

\section{Biodegradation of Human Hair Proteins in Fiber Matrix}

Finally, we examined the sensitivity of HPF towards a protease, chymotrypsin, for evaluation of the biodegradation property of the HPF samples. The 7\%-HPF sample is exposed to a chymotrypsin solution for enzymatically digesting the human hair proteins in the fiber matrices, and then the amounts of the remaining proteins were determined by means of the Shindai method extraction, followed by the Bradford's assay for protein quantification. The time course of the remaining percentage of human hair proteins in the 7\%-HPF is shown in Figure 5a. After 30 min, approximately $80 \%$ of human hair proteins in the $7 \%-\mathrm{HPF}$ remained undigested. As the digestion reaction proceeds, the remaining percentage of the human hair proteins decreases to less than $70 \%$ at $60-90$ min. After 120 min, $40 \%$ of human hair proteins were lost (remaining, 60\%).

The Bradford's protein assay method is based on the colorimetry when the CBBG-250 indicator dye binds to the hydrophobic moiety of the peptides or proteins. ${ }^{[35]}$ So that this assay method is not appropriate for detecting the decreases of molecular weights accompanying with the enzymatic digestion of the human hair proteins, especially for type I and II keratins. Hence, the enzymatic digestion of two keratins was directly monitored by SDS-PAGE (Figure 5b and 5c). Both types I and II keratins were not found in the extract from 7\%-HPF after 30 min (Figure 5c, lanes 3-7). This fact, together with the result from the Bradford's protein assay (Figure 5a), clearly indicates that the major part of the two keratins in the HPF matrices are digested within $30 \mathrm{~min}$ and that the digested fragments of keratins are slowly solubilized from the HPF matrices.

Figure 6 represents the changes in surface morphologies of 7\%-HPF upon enzymatic digestion. Before digestion, the particles were found on the 7\%-HPF surface (Figure 6a) as seen also in Figure 2. The particles remarkably disappeared after 60 min (Figure 6b). On the other hand, the fibril structure was retained after $120 \mathrm{~min}$ (Figure 6c). These observations indicate that the human hair proteins incorporated in the HPF matrix are actually digested by chymotrypsin and also imply that the surface particles of the HPF are composed of the human hair keratins.

\section{Conclusions}

The human hair protein-gellan-chitosan hybrid fibers are conveniently produced with the simple and ambient procedures. The resulting hybrid fiber can be recognized as a new type of the regenerated human hair keratin fiber, because of its high purity and content of keratins. One of the important achievements in the present study is that the human hair has been successfully developed as a useful and renewable biomass for the engineering fiber materials.

In conclusion, the material design concepts proposed in the present study have been realized as follows: (i) fabrication from only natural polymers; (ii) it does not require any of a high temperature, a high pressure, and a strong acidic or basic condition, but an ambient and 
spontaneous polymer chemical reaction in aqueous media; (iii) simple procedure and apparatus for production; (iv) low-cost solvents for spinning; (v) practical mechanical strength of the resulting fiber; (vi) renewable in the ecological system. Recently, we reported several reinforcement technologies for the watery hybridization spinning system by introducing the crosslinkable functionalities, which are responsible to inter-polymer reactions induced by light irradiation ${ }^{[37]}$ and oxidative enzymes. ${ }^{[38,39]}$ Applying these technologies to the fabric system in this study, the mechanical properties of the human hair protein-gellan-chitosan hybrid fibers could be modified with the physical or biochemical features of natural occurrences. Furthermore, the human hair protein-chitosan-gellan hybrid capsule is also prepared from the similar procedure as described by us. ${ }^{[40]}$ Thus, the human hair hybrid materials are a very promising material for a broad spectrum of applications.

Acknowledgements: This work was supported by Grants-in-Aid for 21st century COE program and Scientific Research (No. 13555178 and No. 14750709) from the Ministry of Education, Culture, Sports, Science, and Technology of Japan. The author thanks to Mr. Masakazu Hachisu of this institute.

\section{References}

[1] R. D. B. Fraser, T. P. MacRae, "Conformation in Fibrous Proteins: and Related Synthetic Polypeptides", Academic Press, New York, 1973.

[2] P. H. Hermans, "Physics and Chemistry of Cellulose Fibers: with Particular Reference to Rayon", Elsevier Publishing Company, Inc., New York, 1949.

[3] R. L. Wormell, "New Fibers from Proteins", Butterworths Scientific Publications, London, 1954.

[4] C. J. Bailey, H. J. Woods, Nature 1968, 218, 765.

[5] J. W. Hearle, Int. J. Biol. Macromol. 2000, 27, 123.

[6] M. L. Huggins, Macromolecules 1977, 10, 893.

[7] T. Asakura, J. Yao, T. Yamane, K. Umemura, A. S. Ulrich, J. Am. Chem. Soc. 2002, 124, 8794.

[8] C. L. Craig, C. Riekel, Comp. Biochem. Physiol. B: Biochem. Mol. Biol. 2002, 133, 493.

[9] A. Nakamura, M. Arimoto, K. Takeuchi, T. Fujii, Biol. Pharm. Bull. 2002, 25, 569.

[10] T. Fujii, D. Ogiwara, M. Arimoto, Biol. Pharm. Bull. 2004, 27, 89.

[11] T. Fujii; Y. Ide, Biol. Pharm. Bull. 2004, 27, 1433.

[12] Y. Ide, T. Fujii, Kobunshi Ronbunshu 2004, 61, 190.

[13] J. M. Gillespie, In: "Biochemistry and Physiology of the Skin I"; L. A. Goldsmith, Ed., Oxford University Press, London 1983, p. 475.

[14] G. E. Rogers, Ann. N.Y. Acad. Sci. 1985, 455, 403.

[15] H. P. Lundgren, W. H. Ward, In: "Ultrastructure of Protein Fibers"; R. Borasky, Ed., Academic Press, Inc., New York 1963, p. 39.

[16] F. Happey, R. L. Wormell, J. Tex. Inst. 1949, 40, T855.

[17] R. L. Wormell, F. Happey, Nature 1949, 163, 18.

[18] Us. 3642498 (1972), General Mills, Inc.: C. A. Anker.

[19] Us. 2814851 (1957), Rubberset Co.: L. R. B. Hervey.

[20] Jp. 05106106 (1993), Kurashiki Boseki Kk, Japan.: T. Ikeda; M. Yamada; S. Nojima; T. Kondo; F. Sakai.

[21] K. P. McGrath, M. M. Butler, Protein-Based Materials 1997, 257.

[22] A. E. Pavlath, C. Houssard, W. Camirand, G. H. Robertson, Tex. Res. J. 1999, 69, 539.

[23] K. Ulbert, Nature 1962, 195, 175.

[24] K. Yamauchi, A. Yamauchi, T. Kusunoki, A. Kohda, Y. Konishi, J. Biomed. Mater. Res. 1996, 31, 439. 
[25] M. Hachisu, K. Ohkawa, H. Yamamoto, Macromol. Biosci. 2003, 3, 92.

[26] D. Satoyoshi, M. Hachisu, M. Amaike, K. Ohkawa, H. Yamamoto, Macromol. Mater. Eng. 2004, 289, 495.

[27] K. Ohkawa, H. Yamamoto, In: "Biopolymers" Vol. 7, A. Steinbühel, S. R. Fahnestock, Eds., Wiley-VCH, Weinheim 2003, chapter 15, p. 465.

[28] H. Yamamoto, K. Ohkawa, In: "Encyclopedia of Surface and Colloid Science"; A. Hubbard, Ed., Marcel Dekker, Inc, New York 2002, p. 4242.

[29] H. Yamamoto, Y. Senoo, Macromol. Chem. Phys. 2000, 201, 84.

[30] M. Amaike, Y. Senoo, H. Yamamoto, Macromol. Rapid Commun. 1998, 19, 287.

[31] K. Ohkawa, M. Yamada, A. Nishida, N. Nishi, H. Yamamoto, J. Polym. Environ. 2000, 8, 59.

[32] Y. Takahashi, K. Ohkawa, M. Ando, M. Yamada, H. Yamamoto, Macromol. Mater. Eng. 2001, 286, 733.

[33] W. Gibson, In: "Thickening and Gelling Agents for Food"; A. Imeson, Ed., Chapman \& Hall, London 1992, p. 227.

[34] R. A. A. Muzzarelli, "Chitin", Pergamon, Oxford, 1977.

[35] M. M. Bradford, Anal. Biochem. 1976, 72, 248.

[36] U. Laemmli, Nature 1970, 227, 680.

[37] K. Ohkawa, K. Shoumura, Y. Shirakabe, H. Yamamoto, J. Mater. Sci. 2003, 38, 3191.

[38] Y. Kuboe, H. Tonegawa, K. Ohkawa, H. Yamamoto, Biomacromolecules 2004, 5, 348.

[39] H. Tonegawa, Y. Kuboe, M. Amaike, A. Nishida, K. Ohkawa, H. Yamamoto, Macromol. Biosci. 2004, 4, 503.

[40] K. Ohkawa, T. Kitagawa, H. Yamamoto, Macromol. Mater. Eng. 2004, 289, 33. 


\section{Figures and Captions}
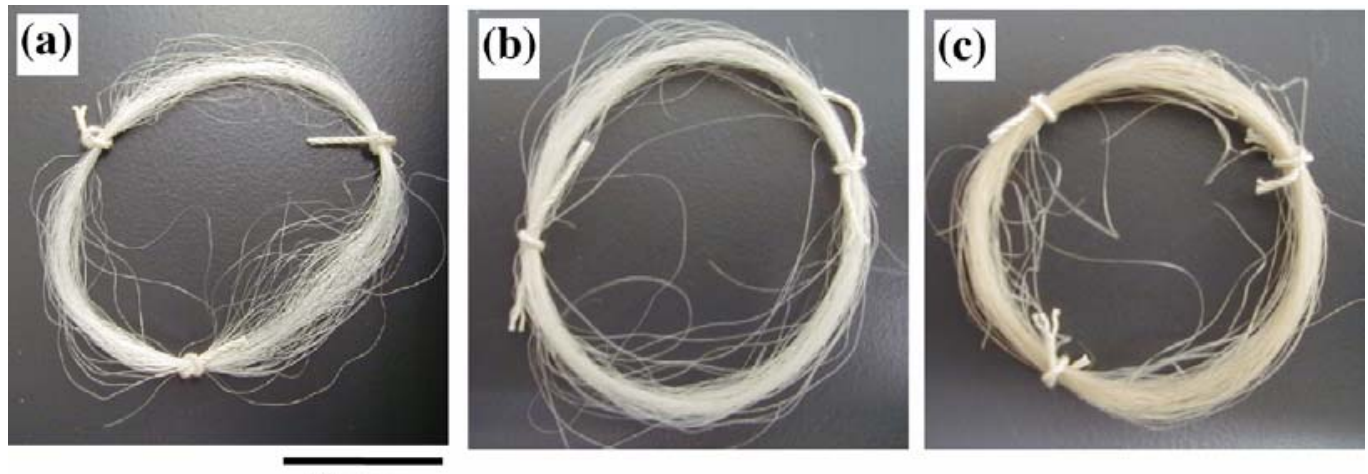

$20 \mathrm{~mm}$
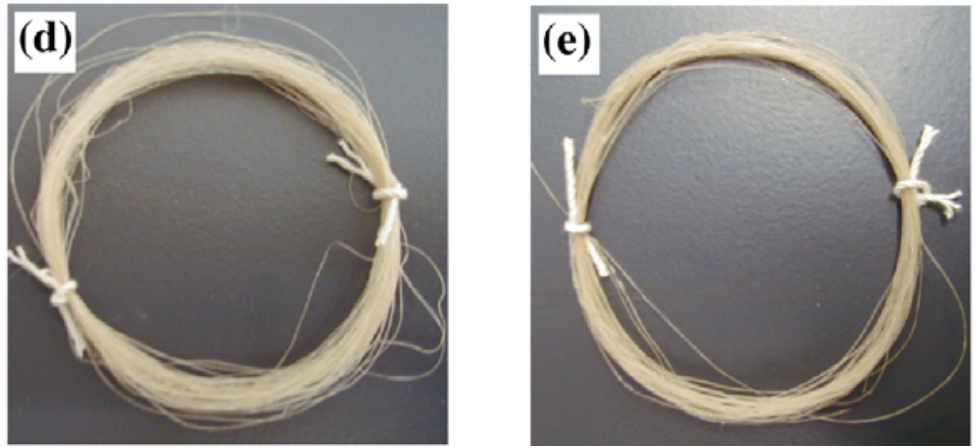

Figure 1. Photographs of the human hair protein-gellan-chitosan hybrid fibers (HPFs): (a), the gellan-chitosan fiber; (b), 7\%-HPF; (c), 16\%-HPF; (d), 23\%-HPF; (e), 35\%-HPF. Scale bar is $20 \mathrm{~mm}$. 

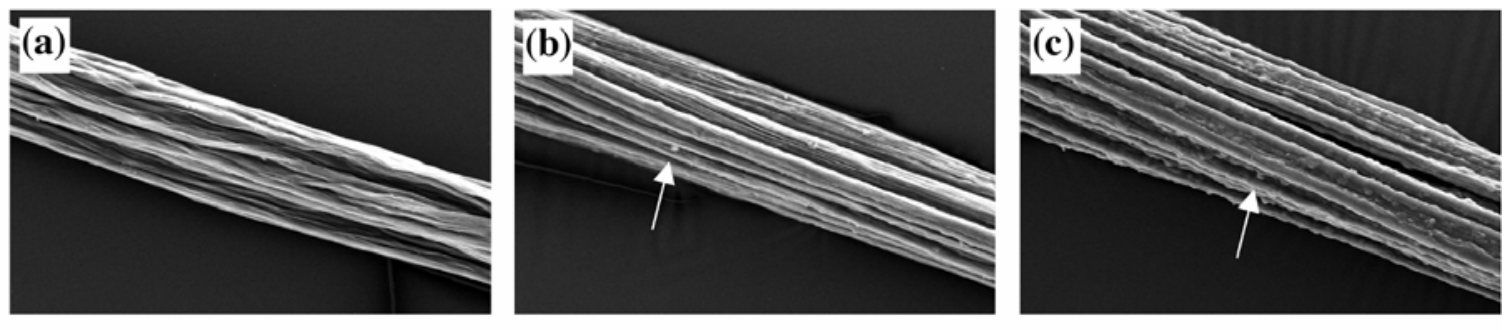

$100 \mu \mathrm{m}$
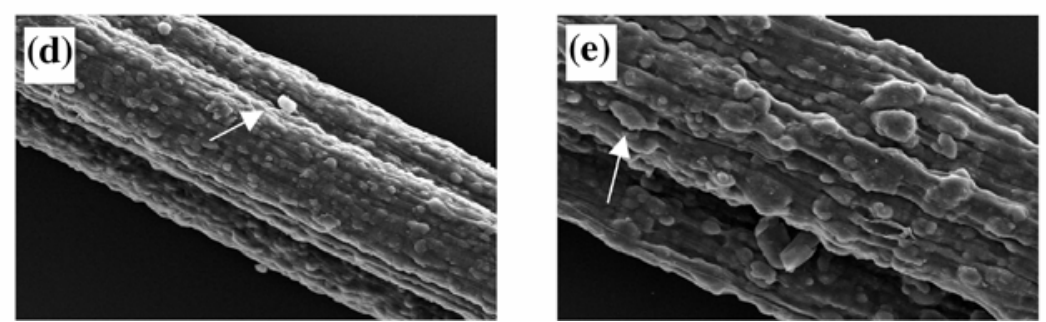

Figure 2. SEM images of the human hair protein-gellan-chitosan hybrid fibers (HPFs): (a), the gellan-chitosan fiber; (b), 7\%-HPF; (c), 16\%-HPF; (d), 23\%-HPF; (e), 35\%-HPF. Scale bar is $100 \mu \mathrm{m}$ (Magnification, $\times$ 500). Arrows indicate the particle found on the fiber surfaces. 


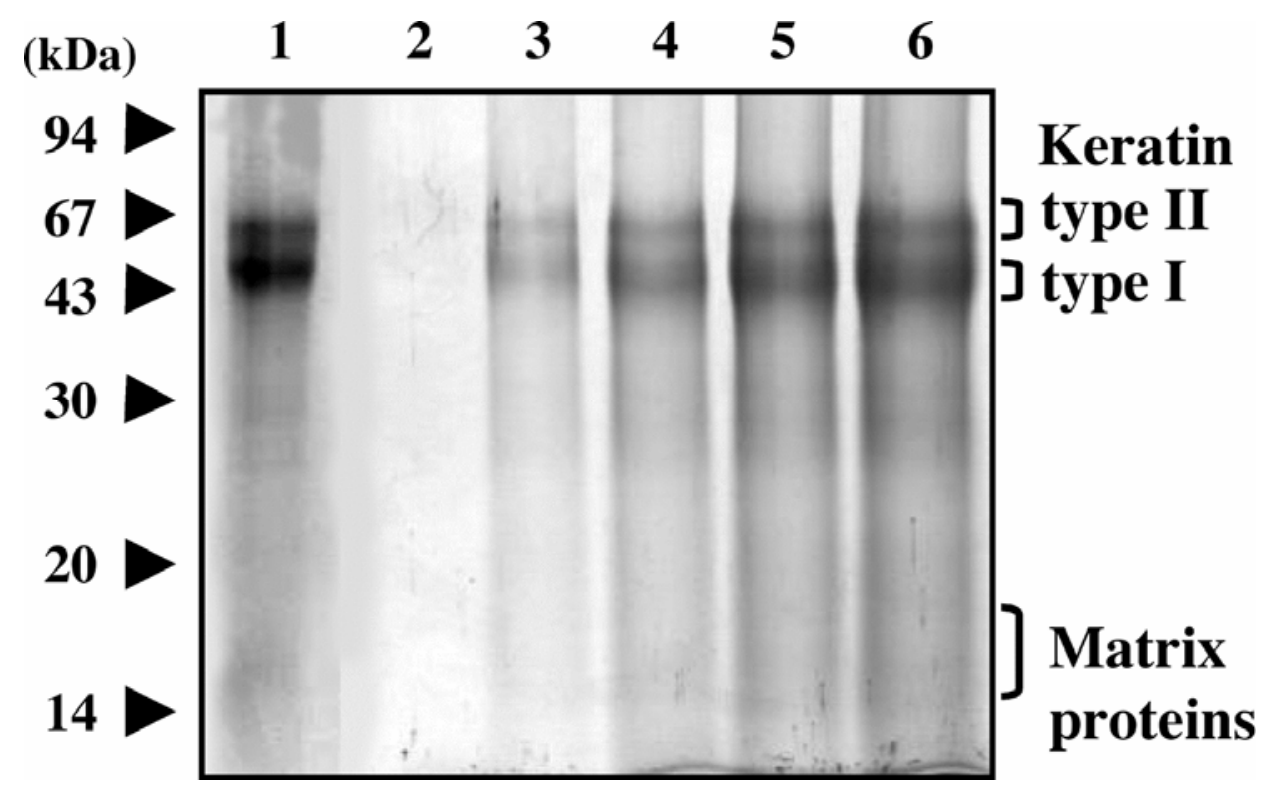

Figure 3. SDS-PAGE analysis of the protein extracts prepared by the Shindai method: lane 1, extract from native human hair; lane 2, gellan-chitosan fiber; lane 3, 7\%-HPF; lane 4, 16\%-HPF; lane 5, 23\%-HPF; lane 6, 35\%-HPF. 


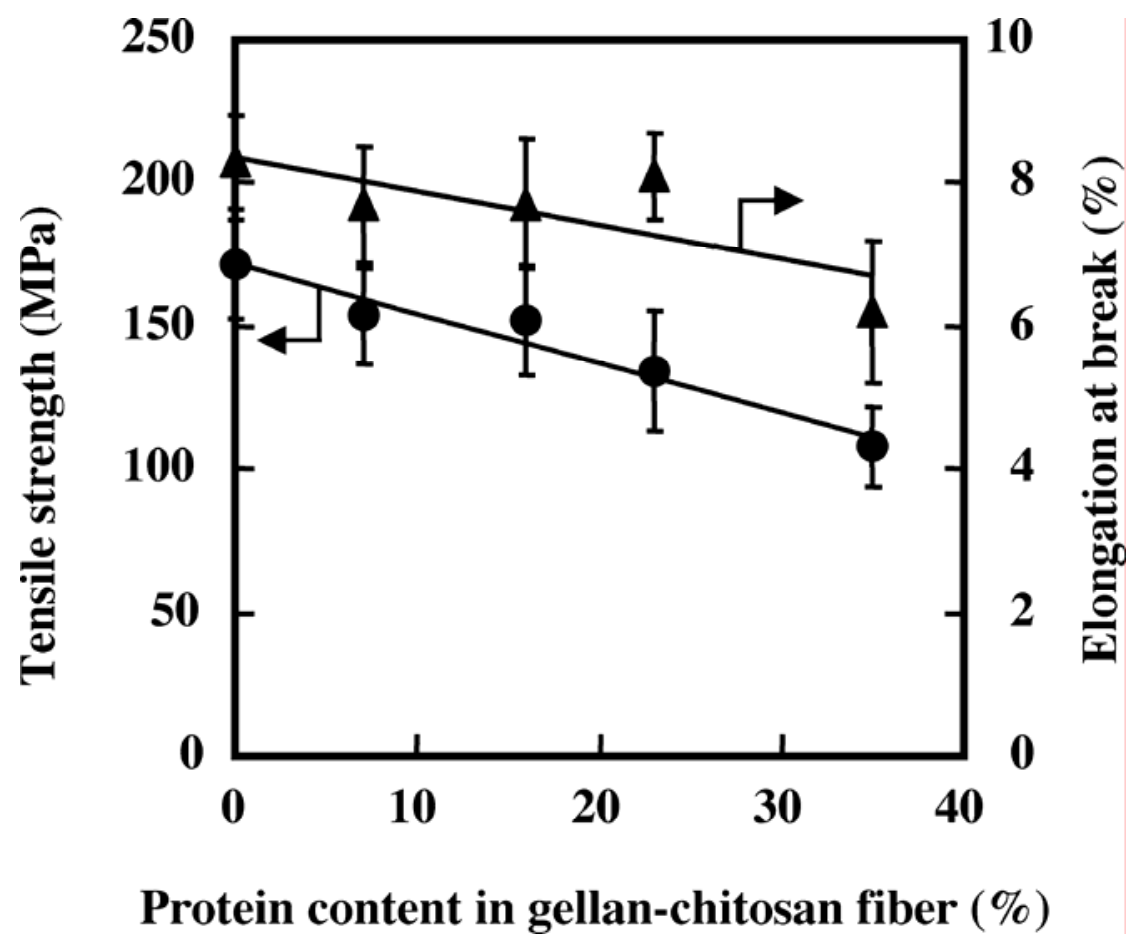

Figure 4. Relationship between the content of human hair proteins in the gellan-chitosan fiber and the tensile strength (closed circles) or the elongation at break (closed triangles). 
(a)

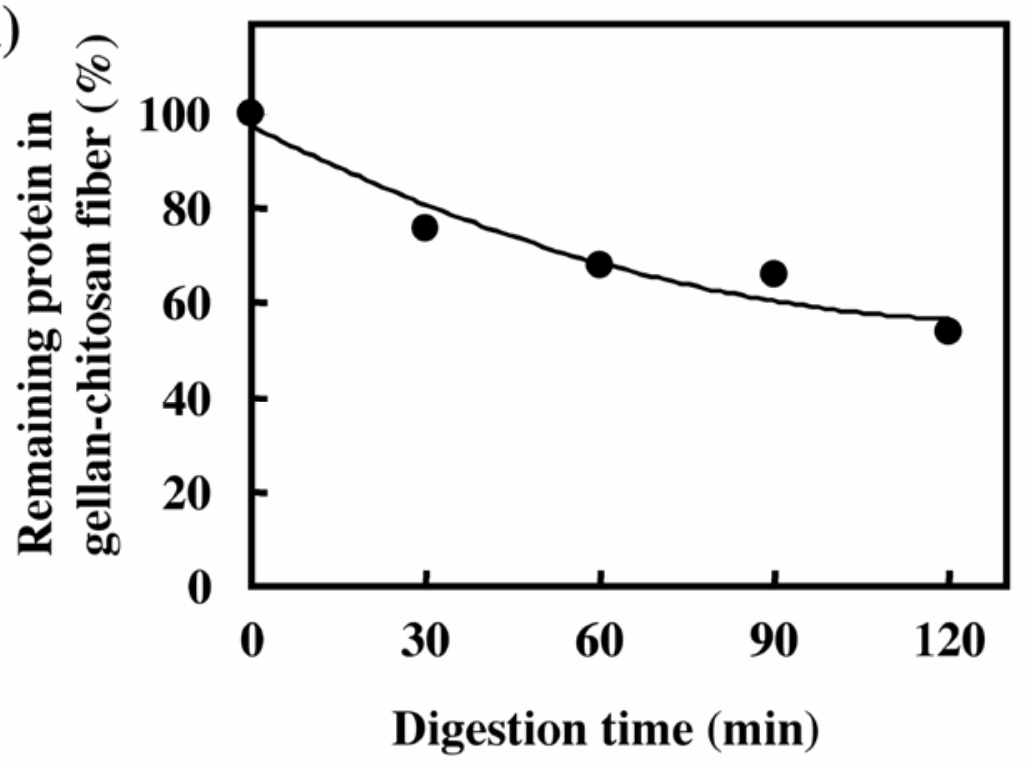

(b)

(c)

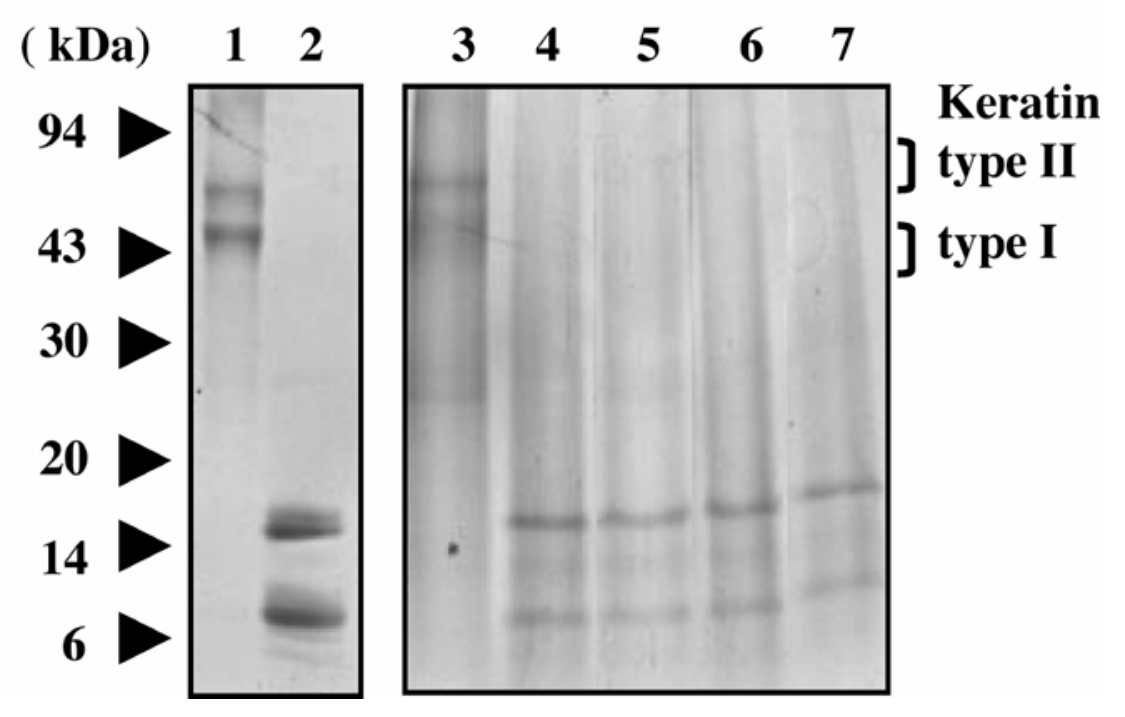

Figure 5. (a) Time course of the remaining proteins (\%) in the 7\%HFP upon enzymatic digestion by chymotrypsin. (b) SDS-PAGE analysis on the protein composition: lane 1, extract from native human hair; lane 2, chymotrypsin. (c) Extracts from chymotrypsin-digested 7\%-HPF; lane 3; before digestion; lane 4, after $30 \mathrm{~min}$; lane 5, $60 \mathrm{~min}$; lane 6, $90 \mathrm{~min}$; lane 7, $120 \mathrm{~min}$. 

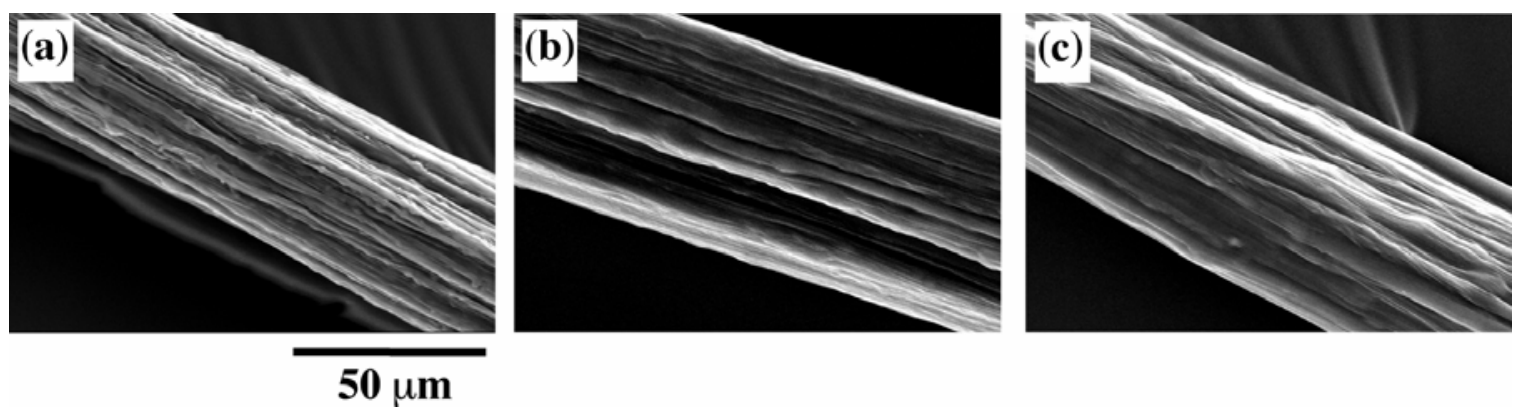

$50 \mu \mathrm{m}$

Figure 6. SEM images of the 7\%-HPF after treatment with chymotrypsin: (a), 0 min; (b), 60 min; (c), $120 \mathrm{~min}$. Scale bar is $50 \mu \mathrm{m}$. 


\title{
Table-Of-Content Text and Graphic
}

\section{A Novel Human Hair Protein Fiber Prepared by Watery Hybridization Spinning}

\author{
Y. Hirao, K. Ohkawa, H. Yamamoto, T. Fujii*
}

Full Paper. A novel human hair protein hybrid fiber was developed by combining (i) the high-efficiency extraction technique for preparing human hair proteins and (ii) the watery hybridization spinning method using gellan and chitosan (Figures a, gellan-chitosan hybrid fiber; $b$, human hair protein-gellan-chitosan hybrid fiber). The hybrid fiber can be recognized as a new type of the human hair keratin fiber, because of its high purity and content of human hair keratin types I and II. The practical mechanical strength and the excellent biodegradability of the hybrid fibers imply its broad spectrum of applications, especially as the medical engineering fibers.
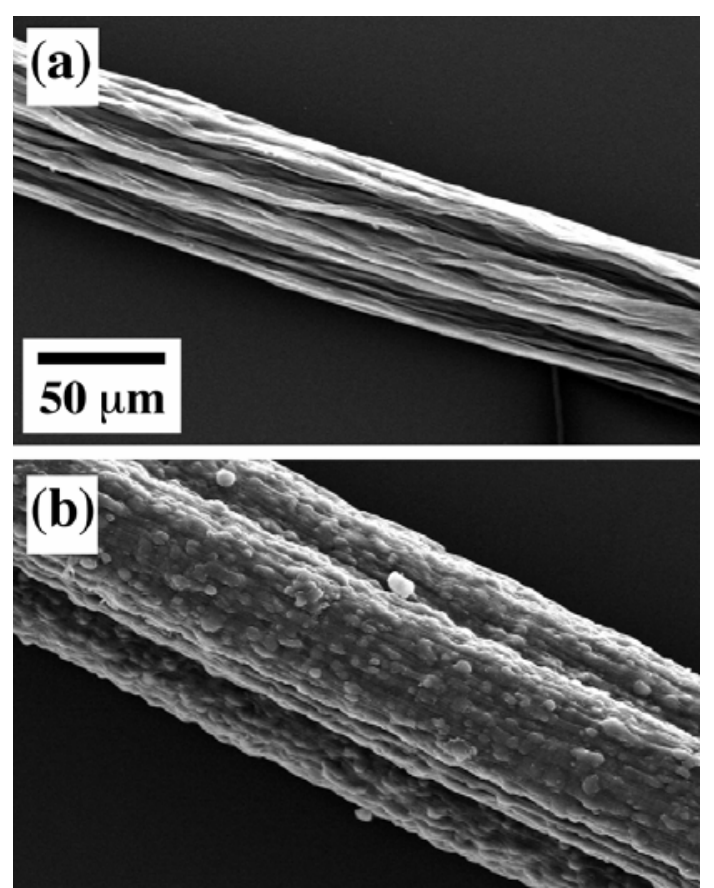